TOMASZ R. SZYMCZYŃSKI

Uniwersytet im. Adama Mickiewicza w Poznaniu

DOI : $10.14746 /$ rie.2016.10.5

\title{
Brexit a wyzwania identyfikacyjne w odniesieniu do procesu integracji europejskiej z perspektywy hermeneutycznej ${ }^{1}$
}

\section{Wprowadzenie}

Przeprowadzone 23 czerwca 2016 roku referendum w Wielkiej Brytanii na temat przyszłości tego państwa w Unii Europejskiej przyniosło decyzję o opuszczeniu przez Zjednoczone Królestwo europejskich struktur integracyjnych. W rezultacie mamy do czynienia $\mathrm{z}$ bezprecedensowym wydarzeniem $\mathrm{w}$ ramach europejskiego procesu integracyjnego. Choć z formalnego punktu widzenia w odniesieniu do historycznego wymiaru zmian kształtów WE/UE nie jest to pierwszy przypadek opuszczenia struktur wspólnotowych w efekcie negatywnego wyniku referendum ${ }^{2}$, to jednak kontekst wydarzeń z połowy 2016 roku sugeruje, by aktualną sytuację w Unii Europejskiej można było określić jako największy kryzys tego ugrupowania od początku jego funkcjonowania.

Należy podkreślić, że w odniesieniu do wydarzenia polityczno-społecznego, które otrzymało etykietę - Brexit warto naświetlić jego dwa zasadnicze znaczenia. W węższym rozumieniu Brexit należy odnosić do referendum z dnia 23 czerwca 2016 roku, natomiast w ujęciu szerszym Brexitem możemy nazywać także cały proces opuszczania Unii Europejskiej przez Wielką Brytanię, wraz z konsekwencjami tego wydarzenia. $Z$ tego punktu widzenia obecnie dysponujemy znacznie większym zasobem wiedzy względem samego referendum, natomiast wiele kluczowych zagadnień, które będą się składać na proces wyjścia Zjednoczonego Królestwa z UE pozostaje nieznane.

Proces wychodzenia Wielkiej Brytanii z Unii Europejskiej przynosi zatem wiele niezwykle istotnych wyzwań interpretacyjnych, których aspektem wspólnym zdają się być zagadnienia identyfikacyjne. W pierwszej kolejności uderza fakt wielowymiarowości potencjalnych konsekwencji wynikających z pojedynczej decyzji dokonanej

${ }^{1}$ Niniejszy artykuł został napisany w ramach projektu finansowanego przez Narodowe Centrum Nauki: Unia Europejska wobec przyspieszonego rozwoju Chińskiej Republiki Ludowej, 2013/11/B/ HS5/03572.

${ }^{2} \mathrm{~W}$ rezultacie pierwszego rozszerzenia północnego Wspólnot Europejskich (WE), 1-ego stycznia 1973 roku w skład państw członkowskich WE weszła Wielka Brytania, Irlandia oraz Dania wraz z Grenlandią. W referendum, które odbyło się w dniu 23 lutego 1982 r. mieszkańcy Grenlandii opowiedzieli się za opuszczeniem Wspólnot. Przy frekwencji wynoszącej 74,9\% uprawnionych do głosowania, 52,0\% oddających głos opowiedziało się za opuszczeniem europejskich struktur integracyjnych (Szymczyński, 2007; Szymczyński, 2009a; Szymczyński, 2009b; Szymczyński, 2009c; Szymczyński, 2009d; Szymczyński, 2009e; Szymczyński, 2010). 
przez obywateli brytyjskich w oparciu o tradycyjną instytucję demokracji bezpośredniej. Choć zasadnicza idea referendum zakłada, by wszyscy uprawnieni do oddania głosu członkowie określonego zrzeszenia mieli możliwość wypowiedzenia się w pewnej sprawie, właśnie potencjalne konsekwencje brytyjskiego referendum ukazują w wymiarze praktycznym wyzwania wynikające z sytuacji, gdy określone zrzeszenie opiera się na wielopoziomowej strukturze identyfikacyjnej (patrz szerzej: Szymczyński, 2010).

W konsekwencji podjęta przez obywateli brytyjskich w ramach referendum decyzja o opuszczeniu UE nie przynosi zmian wyłącznie w statusie Zjednoczonego Królestwa, lecz także w statusie całej Unii Europejskiej, jak również w statusie pozostałych dwudziestu siedmiu jej państw członkowskich. Z tego punktu widzenia ukazuje się zasadnicze wyzwanie, które uwidacznia się w konsekwencji brytyjskiego referendum. Jednym z kluczowych aspektów, które należy uznawać za wartość, a które przynosi uczestnictwo w europejskim procesie integracyjnym państwom członkowskim UE jest ich pozycja w wymiarze globalnym, a zatem pozycja Unii Europejskiej w jej zewnętrznym wymiarze. Choć należy przyjąć, że społeczeństwa poszczególnych państw członkowskich UE będą różnie szacować pozycję swojego państwa w powyższym ujęciu w kontekście potencjalnego opuszczenia Unii Europejskiej, to wydaje się, że zmiana statusu państwa na poziomie globalnym pozostawać będzie raczej poza zbiorem głównych argumentów $\mathrm{w}$ trakcie debaty publicznej poprzedzającej referendum na temat opuszczenia europejskich struktur integracyjnych. Powyższy wniosek opiera się na założeniu o tradycyjnie silnych konotacjach instytucji referendum z kwestiami odnoszącymi się do wewnętrznych spraw biorącego w tego rodzaju formule demokracji bezpośredniej zrzeszeniu.

Wydarzenie określane jako Brexit z niezwykłą siłą wskazuje zatem na wyzwania związane z problemami identyfikacyjno-definicyjnymi zarówno $\mathrm{w}$ odniesieniu do europejskiego procesu integracyjnego, jak i do dynamicznie transformujących się standardów działania i przekazywania informacji w ramach suwerennych państw narodowych w kontekście uobecniających się czynników określanych jako wynikające zarówno z procesu europeizacji, jak i globalizacji. Na tym tle ukazuje się między innymi wyzwanie związane $\mathrm{z}$ zagadnieniem odpowiedzialności poszczególnych grup zawodowych w odniesieniu do formy oraz treści przekazywanych informacji w przestrzeni publicznej (Szymczyński, 2011b). Tego rodzaju optyka prowadzi z kolei do pytań o rolę reprezentantów nauk społecznych i humanistycznych w przestrzeni polityki, a zatem o interakcje między polem polityki i polem nauki o niej. Tak ujęte kwestie prowadzą natomiast do pytań wiążących się z zagadnieniami mieszczącymi się w obszarze, który można określić jako świadomość metodologiczna powyższej dyscypliny naukowej (Szymczyński, 2013).

Dodatkowo, może się okazać, że zrzeszenie obywateli brytyjskich, które dzięki założeniom identyfikacyjnym w odniesieniu do wystarczającego w powyższym kontekście poziomu swej jednorodności uzyskało legitymację do decyzji w kwestii wyjścia z UE, w konsekwencji tejże być może przestanie istnieć w takiej formie, w jakiej podjęło powyższą decyzję. Sytuacja taka nastąpi, gdy obywatele Szkocji lub Irlandii Północnej zrealizują obecne zapowiedzi o pragnieniu opuszczenia Zjednoczonego Królestwa oraz akcesji do Unii Europejskiej. 


\section{Brexit czyli wyjście z UE wpisane w nieoficjalną nazwę referendum}

W przeprowadzonym 23 czerwca 2016 roku referendum w Zjednoczonym Królestwie Wielkiej Brytanii i Irlandii 51,89\%, a zatem większość głosujących, opowiedziała się za wyjściem tego państwa z Unii Europejskiej. W ramach wydarzenia, które uzyskało potoczną nazwę „Brexit” - które jest zbitką słów „Britain” (Brytania) oraz „exit” (wyjście) - za pozostaniem w UE głosowało 16141241 brytyjskich obywateli, natomiast za opuszczeniem 17410742 osób, przy czym frekwencja wyniosła 72,2\%.

Tabela 1

\section{Pytanie w referendum w Wielkiej Brytanii z 23 czerwca 2016 roku}

\begin{tabular}{|l||}
\hline $\begin{array}{l}\text { Should the UK: } \\
\text { [ ] Remain a member of the European Union? } \\
\text { [ ] Leave the European Union? }\end{array}$ \\
\hline $\begin{array}{l}\text { Czy WB powinna: } \\
\text { [ ] Pozostać państwem członkowskim Unii Europejskiej? } \\
\text { [ ] Opuścić Unię Europejską? }\end{array}$ \\
\hline
\end{tabular}

Źródło: Opracowanie własne na podstawie: http://www.bbc.com, 29.09.2016.

Powyższy rezultat oznacza, iż 1269501 głosów więcej zostało oddane na opcję wskazującą na wyjście z UE. Choć zatem w formie postawionego w ramach referendum pytania możliwość pozostania Wielkiej Brytanii w UE została usytuowana jako pierwsza (patrz: tab. 1) to jednak potoczna nazwa tego wydarzenia - Brexit (Britain + exit), która przyjęła się w środkach społecznego przekazu na długo przed dniem samego referendum, uwydatniając opcję opuszczenia europejskich struktur integracyjnych, niemal całkowicie zdominowała powyższą przestrzeń względem swej potencjalnej konkurentki - nazwy Bremain (Britain + remain), która sugerowałaby pozostanie w Unii Europejskiej.

Jednocześnie należy zwrócić uwagę, iż pośród wielu bardziej szczegółowych informacji, które składałyby się na pogłębiony obraz powyższego zdarzenia, wyjątkowo interesująco jawi się rozłożenie wyników w poszczególnych częściach Zjednoczonego Królestwa, jak i w poszczególnych grupach wiekowych. W pierwszym z wymienionych kontekstów, rezultaty czerwcowego referendum ukazały, że za opuszczeniem Unii Europejskiej opowiedziała się większość Anglików (53\% głosujących) oraz Walijczyków (52,5\%). Natomiast zarówno Szkoci (62\% za pozostaniem WB w UE), jak i mieszkańcy Irlandii Północnej (56\% za pozostaniem w UE) oraz szczególnie Gibraltaru $(95,9 \%$ za pozostaniem przy frekwencji sięgającej 83,5\%) zagłosowali przeciwko opuszczaniu europejskich struktur integracyjnych (patrz: tab. 2).

Przynajmniej równie interesująco prezentują się wyniki zbiorowej decyzji Brytyjczyków na temat ich przyszłych relacji z Unią Europejską przy uwzględnieniu poszczególnych grup wiekowych (patrz: tab. 3). W przedziale osób w wieku pomiędzy 18 a 24 rokiem życia za pozostaniem Zjednoczonego Królestwa w Unii Europejskiej opowiedziało się aż 73\%, wśród głosujących pomiędzy 25 a 34 rokiem życia $62 \%$ wybrało pozostanie w UE, a pośród obywateli brytyjskich w wieku od 35 do 44 lat za pozostaniem głosowało $52 \%$. 
Wyniki referendum w Wielkiej Brytanii z 23 czerwca 2016

\begin{tabular}{|c|c|c|c|c|c|}
\hline & \multicolumn{2}{|c|}{ Z Za wyjściem z UE } & \multicolumn{2}{|c|}{ Za pozostaniem w UE } & \multirow{2}{*}{ Frekwencja } \\
\hline & liczba osób & $\%$ & liczba osób & $\%$ & \\
\hline Wielka Brytania & 17410742 & $51,9 \%$ & 16141241 & $48,1 \%$ & $72,2 \%$ \\
\hline Anolia & & & & & \\
\hline & 15100400 & $3,0,0$ & 15200990 & 41,070 & $73,0 \%$ \\
\hline Walia & 854572 & $52,5 \%$ & 772347 & $47,5 \%$ & $71,7 \%$ \\
\hline Szkocja & 1018322 & $38,0 \%$ & 1661191 & $62,0 \%$ & $67,2 \%$ \\
\hline Irlandia Północna & 349442 & $44,0 \%$ & 440707 & $56,0 \%$ & $62,7 \%$ \\
\hline Gibraltar & 823 & $4,1 \%$ & 19322 & $95,9 \%$ & $83,5 \%$ \\
\hline
\end{tabular}

Źródło: Opracowanie własne na podstawie: http://www.electoralcommission.org.uk, 29.09.2016.

Dopiero wśród mieszkańców Wielkiej Brytanii w przedziale wiekowym 45-54 lat tendencja ukazuje się odmiennie, gdyż tutaj większość (56\%) optuje za wyjściem. Niemal identycznie wygląda zestawienie głosów w przedziale wiekowym 55-64, gdzie decyzję o wyjściu z UE podjęło 57\% uczestników referendum. Z kolei pośród Brytyjczyków powyżej sześćdziesiątego czwartego roku życia 60\% głosowało za opuszczeniem europejskich struktur integracyjnych. Powyższe zestawienie jednoznacznie ukazuje korelację między wiekiem uczestników czerwcowego referendum a ich opinią w odniesieniu do przyszłych losów Zjednoczonego Królestwa w Unii Europejskiej, gdzie wraz z wiekiem głosujących podwyższa się ich sceptycyzm względem udziału Albionu w europejskim projekcie integracyjnym.

Tabela 3

\section{Wyniki brytyjskiego referendum z 23 czerwca 2016} uwzględniające podział na grupy wiekowe

\begin{tabular}{||c|c|c||}
\hline \hline Grupa wiekowa & Za wyjściem z UE & Za pozostaniem w UE \\
\hline $18-24$ & $27 \%$ & $73 \%$ \\
\hline $25-34$ & $38 \%$ & $62 \%$ \\
\hline $35-44$ & $48 \%$ & $52 \%$ \\
\hline $45-54$ & $56 \%$ & $44 \%$ \\
\hline $55-64$ & $57 \%$ & $43 \%$ \\
\hline $65+$ & $60 \%$ & $40 \%$ \\
\hline
\end{tabular}

Źródło: Ashcroft, 2016.

Z tego punktu widzenia na uwagę zasługują głosy krytykujące niedopuszczenie szesnasto- i siedemnastolatków do udziału w czerwcowym referendum. Koronnym argumentem w tym kontekście było przy tym wskazywanie na formułę zastosowaną w referendum na temat niepodległości Szkocji, które odbyło się 18 września 2014 roku, a w którym czynne prawo do głosowania objęło powyższe grupy wiekowe (https://www.gov.uk).

Niosąc wiele niezwykle istotnych pytań problemowych, na które odpowiedzi są obecnie nieznane, Brexit, czyli proces wychodzenia Wielkiej Brytanii z Unii Europej- 
skiej, już dziś dobitnie wskazuje, że strategię konsekwentnego omijania w ostatnich latach prób zmierzenia się z zagadnieniami identyfikacyjno-definicyjnymi w odniesieniu do europejskiego procesu integracyjnego należy uznać za błędną. A wysoki stopień trudności, który wiąże się z tego typu próbami nie powinien przy tym stanowić wystarczającego argumentu, by z nich rezygnować.

\section{Unia Europejska czyli system polityczny, który nie jest państwem}

Nie ulega wątpliwości, iż Unia Europejska jest ze swej natury konstruktem niezwykle specyficznym. Jako projekt przyjęty dobrowolnie przez suwerenne państwa narodowe, stanowi zarazem funkcjonujący ,,[... system polityczny, który nie jest państwem" (Hix, 2005, s. 1; Hix, 2010, s. 27). Z tej perspektywy wymaga dodatkowej uwagi i precyzji w polu językowym, ponieważ jako zjawisko nieposiadające precedensu nie może bazować na konceptualizacjach wynikających z autorytetu opartego na długim trwaniu, czyli na podkreślanej przez wielu myślicieli sile zwyczaju (patrz przykładowo: Pascal, b.d., s. 250; Tocqueville, 1976; Weber, 2002, s. 158 i n.; Bourdieu, 2008, s. 66; Sartori, 1998, s. 259; Gadamer, 2007, s. 390). Zwrócenie uwagi na kwestie związane z potęgą konwencji w omawianym kontekście, która w sposób szczególny ujawnia się na pojęciowym poziomie przynależnej do tego obszaru problematyki o charakterze językowym, oznacza dodatkowo przynajmniej dwa zasadnicze wyzwania.

Po pierwsze, postulat konkretnej i zwięzłej wypowiedzi na temat integracji europejskiej natrafia na przeszkodę w postaci braku jednoznacznych ustaleń pojęciowych, co wynika z faktu względnie nowatorskiego charakteru tego przedsięwzięcia i w efekcie oznacza wymykanie się istniejącym siatkom pojęciowym właściwym zarówno dla pola nauki o polityce, jak i jej subdyscypliny, nauki o stosunkach międzynarodowych. Po drugie, powiązanie - wynikającej z tak rozumianej nowej jakości - niejednoznaczności ustaleń z jednej strony oraz wagi tematu ze strony drugiej, wzmacnia tendencje do niejednokrotnie raczej perswazyjnego, niż możliwie bezstronnego odnoszenia się do analizowanej przestrzeni, skąd najprawdopodobniej można wyprowadzić podstawowe przyczyny utrzymującej się - explicite lub implicite - popularności mechanizmu konstytuującego dwubiegunowy podział na optykę euroentuzjastyczną i eurosceptyczną (Szymczyński, 2011a, s. 71).

Powyższa konstatacja niesie dwa zasadnicze zadania dla zawartych tu rozważań. Po pierwsze, chodzi o podkreślenie wyzwań związanych z próbami realizowania postulatu zakładającego zastosowanie języka dążącego w kierunku neutralizacji zawartości o charakterze wartościującym. Podnosząc świadomość niemożliwości pełnego osiagnięcia tego celu, zastosowana tu strategia narracyjna opiera się zarówno na wykładni Weberowskiego postulatu wolności od wartościowania dokonanej przez Giovanniego Sartoriego, jak również na założeniu możliwie szerokiej perspektywy oglądu, co - w nawiązaniu do słów Anny Zeidler-Janiszewskiej odnoszących się do teoretycznych podstaw optyki realizowanej przez Wolfa Lepeniesa - ma na celu umacniać czynnik neutralizujący (Sartori, 1998, s. 18; Zeidler-Janiszewska, 1996, s. XX). Po drugie, w relacji do wyżej wyprowadzonego postulatu oraz do sugestii Dimitrisa 
N. Chryssochoou, który zwraca uwagę, iż w przestrzeni rozważań na temat powiązań między europejskim procesem integracyjnym a wątkami odnoszącymi się do zagadnień wiążących się z ustaleniami na temat standardów demokracji: ,[...] dyskusja toczy się wokół nie tylko sposobów rozwiązania problemu [...], lecz także samej natury tego problemu" (Chryssochoou, 2007, s. 506), jako fundamentalne wyzwanie należy uznać przyjęcie założeń odnośnie zastosowania określonej perspektywy badawczej. Ujawnia się tu przy tym prymarna kwestia świadomego rozróżnienia między konkurencją celów oraz konkurencją środków, o której w odmiennym kontekście mówił już Max Weber, a która prowadzi do wyzwań natury pojęciowej, które uobecniają się w ramach dokonywanych przez każdego badacza rozstrzygnięć o charakterze zasadniczym, które określane są jako ujęcie początkowe (Weber, 2002, s. 77).

Gabriel Gottfried, epistemolog niemiecki, zwraca uwagę na zasadnicze znaczenie tak wyprowadzonej optyki wskazując, że: „Niektóre problemy wynikają właśnie stąd, że nie zauważa się, jak trudne i błędne jest wyglądające na oczywiste początkowe ujęcie" (Gottfried, 2007, s. 20). Warto zatem podnieść rozróżnienie Webera, by w powiązaniu z przytoczonymi powyżej słowami Chryssochoou podkreślić, że na wstępnym etapie badań poświęconych europejskiemu procesowi integracyjnemu należy uznać obecność konkurencyjnych ujęć zarówno w odniesieniu do metod jego badania (środki), jak i do rozmaitych ujęć tego, co badamy (cel). Uwaga ta niesie w efekcie wniosek, że za jednym terminem «Unia Europejska» znajduje się cały szereg interpretacji, co $\mathrm{w}$ istocie termin ów miałby oznaczać. Powyższy punkt widzenia pozwala zaznaczyć, że w ten sposób przyjęte ramy ujęcia początkowego sugerują, że niezwykle obiecującą w tak zestawionym kontekście jest metoda, która wiąże optykę nauk politycznych z wymiarem hermeneutycznym (Szymczyński, 2013).

\section{Rozumienie wyjaśniające między analityką a hermeneutyką}

Chodzi o dostrzeżenie daleko idących konsekwencji, które wynikają z przyjęcia określonej perspektywy metodologicznej, gdzie na pierwszy plan wysuwa się odniesienie się autora pracy badawczej względem wstępnego rozróżnienia, które Barbara Krauz-Mozer ujmuje jako model analityczno-empiryczny z jednej oraz hermeneutyczno-humanistyczny ze strony drugiej, badacze brytyjscy, David Marsh i Paul Furlong jako stanowisko naukowe (pozytywistyczne) i hermeneutyczne (interpretacjonistyczne) (Krauz-Mozer, 2007, s. 39-51; Marsh, Furlong, 2006, s. 18; Czaputowicz, 2007, s. 403).

Natomiast Jürgen Habermas wychodząc od dwubiegunowego rozróżnienia na nauki przyrodnicze i humanistyczne zastępuje je podziałem trychotomicznym na nauki empiryczno-analityczne, historyczno-hermeneutyczne oraz krytyczne (Habermas, 1982; Habermas, 1988). Jednocześnie niemiecki myśliciel proponuje przekroczenie tak ujętych podziałów, co w opinii Jerzego Szackiego oznacza, iż tym samym ,[...] uchylił w istocie spór o to, do którego z tych rodzajów należy zaliczyć in toto tę czy inną naukę społeczną. [...] Inaczej mówiąc, Habermas [...] uznał procedury właściwe poszczególnym grupom nauk za jednakowo uprawnione pod warunkiem, że stosuje się je we właściwych granicach, nie usiłując zastąpić przez drugie, czy trzecie" (Szac- 
ki, 2002, s. 925). Zarazem, w oparciu o swoją koncepcję trzech rodzajów interesów konstytuujących poznanie (Habermas, 1985, s. 157 i n.), Habermas zakłada wielopostaciowość ujęć racjonalności, której - jak to komentuje Szacki - ,[...] nie może zmonopolizować ani nauka jako taka, ani, tym bardziej, jakikolwiek jeden jej rodzaj. Każdy z tych rodzajów ogarnia inny wymiar rzeczywistości społecznej, zachowując prawomocność odnośnie do niego, ale tylko do niego. Przekraczając swoje granice z nauki zmienia się w ideologię" (Szacki, 2002, s. 926).

Należy zatem podkreślić, że podziały tego rodzaju, u których podstawy znajduje się pragnienie uporządkowania wielu różniących się od siebie podejść obecnych w polu dociekań naukowych o charakterze humanistycznym i społecznym, niosą ze sobą szereg wyzwań. Wśród nich w pierwszym rzędzie na uwagę zasługuje ich określony komponent arbitralności. Przyjmowane w ramach aktywności klasyfikacyjnej wglądy każdorazowo zależą od akceptacji szeregu założeń wstępnych, z których najwyżej niewielka część nie znajdzie się niemal automatycznie w polu potencjalnych kontestacji.

Jako przykład wystarczy wskazać niejednoznaczności związane z zaklasyfikowaniem dokonań Maxa Webera. Z jednej strony Barbara Krauz-Mozer wpisuje tego twórcę socjologii rozumiejącej w ramy modelu hermeneutyczno-humanistycznego (Krauz-Mozer, 2007, s. 47), z drugiej strony Antonino Palumbo i Alan Scott konstatują, iż: „Zarówno nowoczesne nauki polityczne jak i socjologia polityki, przy tym niemalże tego nieświadome, ukształtowane zostały przez niepoddające się jednoznacznym ustaleniom dziedzictwo pism i problematyki wyprowadzonej przez Webera" (Palumbo, Scott, 2008, s. 387). Z kolei Habermas upatruje w Weberowskim postulacie wolności od wartościowania (niem. das Wertfreiheitspostulat) przyczyny stanu rzeczy, który w opinii autora Teorii działania komunikacyjnego polega na zastąpieniu racjonalnej refleksji naukowej na temat praktycznych ustaleń, co do określonych kształtów porządku społecznego założeniami o charakterze decyzji czysto technicznych (Weber, 2011, s. 193 i n; Habermas, 1983; Habermas, 1999; Habermas, 2002; Krasnodębski, 1983, s. 541-542). Tego rodzaju wgląd na temat oddziaływania pism Webera, kieruje sugestie przyporządkowania jego dorobku do pola nauk empiryczno-analitycznych, co można skontrastować z podejściem reprezentowanym przez Grażynę Woroniecką, która zwraca uwagę na hermeneutyczny wymiar Weberowskiego ujęcia, gdy w jego ramach koncepcja rozumienia (niem. Verstehen) oparta zostaje na wstępnym pytaniu «co?», czyli «co działający robią?» (niem. aktuelles Verstehen), by możliwe było przejście na drugi poziom, na którym postawione zostaje pytanie o to «dlaczego?», a zatem «dlaczego to robią?» (niem. erklärendes Verstehen) (Woroniecka, 2005, s. 80; Weber, 2002, s. 8).

Max Weber, określając się sam jako reprezentant nauki empirycznej skierowanej na rozumienia „sensu” podkreślał, że owo pojęcie „sensu” interpretuje w kategoriach motywów znajdujących się u podstaw pewnych konkretnych działań człowieka. W opinii autora Gospodarki i spoteczeństwa może to przy tym przybierać różne formy: „«Sens» oznacza tu subiektywny sens intencjonalny nadawany albo a) faktycznie: $\alpha$ przez działającego $\mathrm{w}$ danym historycznym przypadku lub $\beta$ przeciętnie, $\mathrm{w}$ przybliżeniu, przez działających w masie danych przypadków, albo też b) w pojęciowym konstrukcie - czystym typie przez działającego lub działających ujętych jako typ. Nie 
jest to jakiś sens obiektywnie «właściwy» czy też metafizycznie «prawdziwy». To właśnie odróżnia empiryczne nauki o działaniu [...] od nauk dogmatycznych [...], które starają się dotrzeć do właściwego, obowiązującego sensu swych przedmiotów" (Weber, 2002, s. 6).

W tym kontekście Dirk Kaesler zaznacza, iż: ,pojawia się tu główna przesłanka wszelkich ujęć «rozumiejących», ta mianowicie, że działające osoby wiążą jakiś «sens» ze swoim działaniem i że ten «sens» przynajmniej je współokreśla" (Kaesler, 2010, s. 234). Oparta na takich podstawach idea „rozumienia” przyjmuje zatem, jak zostało już wspomniane, dwa podstawowe jego rodzaje: rozumienie bezpośrednie (niem. aktuelles Verstehen) oraz rozumienie wyjaśniające (niem. erklärendes Verstehen). W ramach pierwszego z nich obecne są trzy warianty: 1) bezpośrednie rozumienie racjonalnego myślenia, 2) bezpośrednie rozumienie irracjonalnych afektów oraz 3) bezpośrednie rozumienie racjonalnych działań. Natomiast rodzaj rozumienia wyjaśniającego, ujmowany przez Kaeslera jako rozumienie motywacji ,[...] docieka symbolicznej jakości obserwowanego działania" (Kaesler, 2010, s. 234-235), co dzięki umiejscowieniu takiej aktywności w określonym kontekście „,[...] zyskuje zrozumiałą dla nas strukturę sensu (racjonalne rozumienie motywacji)" (Weber, 2002, s. 8).

Zatem już na tym etapie rozważań można zaznaczyć, że aktywność badawcza o hermeneutycznej charakterystyce będzie w dużym stopniu koncentrowała uwagę na źródłach znajdujących się u podłoża przyjmowanych sensów, a zatem na możliwych odczytywaniach określonych kontekstów stanowiących nieraz utajoną podstawę sądów jawnych, szczególnie gdy odnoszą się one do treści wpisujących się w wymiar symboliczny.

\section{Wieloznaczność rozumienia wymiaru analitycznego oraz normatywnego}

Inną ilustracją omawianej tu problematyki może być wieloznaczność rozumienia w odniesieniu do tego, co określane jest jako «analityczne». Przykładowo, David Miller i Richard Dagger na wstępie swojej pracy poświęconej współczesnej analitycznej teorii politycznej podkreślają problematyczność tak przyjętej etykiety, by następnie wyprowadzić pięć zasadniczych założeń, które w ich opinii powinny być spełnione, by móc zostać zakwalifikowanym w jej granice.

Po pierwsze, tak rozumiana analityczna teoria polityczna powinna być oddzielona od zagadnień natury metafizycznej w rodzaju pytań o sens życia, istnienie Boga, tudzież miejsce człowieka we wszechświecie, co wiąże się ze zgodą na jej z założenia zsekularyzowany kształt. Po drugie, powinna dążyć do jednoznacznego ujmowania używanych pojęć, czego - zdaniem przytaczanych autorów - prominentnym przykładem może być napisana w 1969 roku praca Isaiah Berlina pt. Dwie koncepcje wolności (Berlin, 2000). Powinna również stosować możliwie przejrzysty język, do czego z kolei nawoływał już John Locke w 1690 roku (Locke, 1992). Po trzecie, jej cel należy ujmować jako normatywny, czyli zmierzający do wyprowadzenia podstawowych założeń, które winny leżeć u podstaw działań o naturze publicznej i z tego punktu widzenia powinna diametralnie różnić się od podejść reprezentujących określone interesy partykularne. Po czwarte, propozycje tego rodzaju każdorazowo muszą świadomie odnieść 
się do kwestii pluralizmu wartości - takich jak wolność, sprawiedliwość, demokracja, dobrobyt ekonomiczny i inne - co oznacza akceptację tezy wyartykułowanej przez Berlina o nierozwiązywalnym konflikcie między nimi (Berlin, 1962), lub przyjęcie założenia o dominującej pozycji jednej z nich, co przykładowo w ujęciu Johna Rawlsa prowadzi do podkreślenia roli sprawiedliwości, a u Roberta Nozicka tak jak u Ronalda Dworkina będą to indywidualne prawa jednostek (Rawls, 1995; Nozick, 1988; Dworkin, 1977). Po piąte, Miller i Dagger sugerują, że analityczna teoria polityczna musi mieścić się w tym, co należy ująć jako w szerokim znaczeniu liberalne, a co oznacza, że przedmiotem jej rozważań pozostają społeczeństwa wolnych i równych obywateli, którzy różniąc się między sobą, co do poszczególnych rozwiązań, akceptować będą zasadnicze mechanizmy służące porządkowaniu sfery publicznej w kontekście uznającym istnienie tego typu odmienności (Miller, Dagger, 2008, s. 387 i n.).

Dla porównania, Philip Pettit ukazuje trzy zasadnicze założenia znajdujące się u podstawy tego, co określa on mianem filozofii analitycznej w jej politycznej odmianie. Jako pierwsze autor ów wskazuje, iż zwolennicy tego typu ujęcia zakładają istnienie rzeczywistości, która jest niezależna od ludzkiego poznania, a której część stanowią ludzie. Jako drugie, iż właściwym sposobem badania tej rzeczywistości jest oparcie się na rozumie i metodzie. Jako trzecie, podniesione zostaje iż: ,podczas takiego badania powinniśmy zawiesić sądy przyjmowane na mocy tradycji - zwłaszcza tradycyjne wartościowania - i pozwolić, by fakty przemawiały same za siebie" (Pettit, 1998, s. 21 i n.).

Odniesienie się w niniejszym fragmencie do tez Pettita ma przy tym spełnić dwa podstawowe zadania. W pierwszej kolejności ma posłużyć jako przykład, jak dalece różniące się od siebie może być pojmowanie przymiotnika «analityczne». W drugiej, ukazać niebezpieczeństwa kryjące się za zbyt pochopnie artykułowanymi opiniami. W tym kontekście wszystkie trzy punkty wyprowadzone przez Pettita pozostają wysoce kontrowersyjne, a szczególnie rzuca się tu w oczy punkt trzeci, gdyż jednym z kluczowych sądów przyjmowanych na mocy tradycji, który w procesie badawczym winniśmy się starać zawiesić jest wysoce naiwna opinia, iż fakty mogą przemawiać same za siebie.

Już wstępne zestawienie ujęć zaprezentowanych przez Millera i Daggera z jednej strony i Pettita z drugiej prowadzi do pytań o właściwe miejsce oraz rozumienie tego, co kryje się za pojęciem «normatywne». W pierwszym z przytoczonych tu przypadków można mówić o niezwykle istotnej roli, jaką tego rodzaju optyka ma do spełnienia w polu współczesnej analitycznej teorii politycznej, gdzie będzie rozumiana jako obszar refleksji nad wartościami, a zatem znaczeniowo pozostawać będzie blisko określenia «aksjologiczne», «deontologiczne» tudzież «preskryptywne». Drugie podejście sugeruje raczej pozostawanie w polu «deskrypcji» i w rezultacie określenie «normatywne», jeśli byłoby w ogóle obecne, należałoby interpretować jako «prawne» (Czachór, 2004, s. 9).

Z kolei oparte na klasyfikacji, którą proponują Cnudde i Neubauer, podejście Giovanniego Sartoriego naświetla powiązanie ujęcia analitycznego z aktywnością kierującą się na znaczenie pojęć (Cnudde, Neubauer, 1969). Sartori w swojej Teorii demokracji podkreśla: „Interesuje mnie raczej możliwa do zastosowania teoria demokracji, oraz to, jak się ona odnosi, i jak przechodzi, do praktyki. [...] Przede wszystkim moje 
teoretyzowanie jest zarówno normatywne jak i opisowe. [...] Co więcej, ponieważ praca ta jest reakcją na czas lub stan zamętu w demokracji, jest mocno dyskursywna i w bardzo dużym stopniu odwołuje się do analizy pojęciowej” (Sartori, 1998, s. 34). Następnie, włoski reprezentant nauk politycznych, odnosząc się do typologii wyprowadzonej przez Cnudde i Neubauera, którzy dokonują rozróżnienia na normatywne, analityczne i empiryczne rodzaje teorii demokracji, dodaje: „Moje teoretyzowanie być może da się sklasyfikować w dużej części jako analityczne w przyjętym przez nich sensie tego terminu, tzn. jako analiza pojęciowa" (Sartori, 1998, s. 36).

\section{Podsumowanie}

Podsumowując niniejsze rozważania należy podkreślić raz jeszcze, że proces wychodzenia Wielkiej Brytanii z Unii Europejskiej niesie wiele niezwykle istotnych pytań problemowych, na które odpowiedzi są obecnie nieznane. Jednocześnie wydarzenie to dobitnie wskazuje, że konsekwentnie omijana w ostatnich latach w państwach UE problematyka zmierzenia się z zagadnieniami identyfikacyjno-definicyjnymi w odniesieniu do europejskiego procesu integracyjnego wraz z aktualnie funkcjonującymi strukturami instytucjonalno-prawnymi zdaje się nie rozwiązywać powyższego problemu, a jedynie odsuwać go w czasie, co jak widzimy w przypadku określonym jako Brexit niesie konsekwencje, których na obecnym etapie nikt nawet nie powinien podejmować się oszacowywać.

Z jednej strony wraz ze wzrostem zainteresowania problematyką demokratyczną oraz legitymizacyjną w badaniach poświęconych integracji europejskiej doszło do „zwrotu normatywnego” (ang. normative turn), co należy bezpośrednio wiązać z rezultatami współpracy Richarda Bellamy’ego i Dario Castiglione (Bellamy, Castiglione, 1997; Bellamy, Castiglione, 2003; patrz także: Bellamy, Attucci, 2009), a co - jak podkreśla Andreas Wimmel - miało utorować drogę do badań nad UE, które włączają w swoje ramy zastosowanie klasycznych pojęć, koncepcji oraz argumentacji obecnych w przestrzeni filozofii praktycznej. A zatem w kontekście uzasadniania rozwiązań funkcjonujących w obszarze wielopoziomowego systemu politycznego Unii Europejskiej, co oznaczałoby jednocześnie przekroczenie dotychczasowych założeń o ograniczeniu tego typu badań do testowania hipotez w ujęciu empirycznym (Wimmel, 2008; Wimmel, 2009; patrz także: Friese, Wagner, 2002).

Z drugiej strony próby realizacji tych niezwykle pożądanych propozycji natrafiają na szereg przeszkód. Wystarczy wskazać tu na znajdujące się pod powierzchnią pojęć wieloznaczności, które mogą wynikać z odmiennych tradycji obecnych w poszczególnych kulturach akademickich. Może to przy tym odnosić się zarówno do różnic wynikających z podziałów na językowe obszary kulturowe (Lepenies, 1997; Koselleck, 1994), jak też konkurencyjne optyki obecne wewnątrz poszczególnych państw (Agné, 2004), ale także towarzyszące aktywności naukowej wewnętrzne aporie poszczególnych uczonych na osi czasu ${ }^{3}$. W szerszym ujęciu, wydarzenie określane jako Brexit

${ }^{3} \mathrm{~W}$ powyższym kontekście chodzi szczególnie o podkreślenie wagi postulatu uwzględniania zjawiska ewoluowania postaw badawczych poszczególnych autorów. Przykładowo, choć urodzony w 1917 roku David Easton uznawany jest za twórcę ogłoszonego w 1953 roku w formie książki 
wskazuje potrzebę prób wypracowywania jakościowo nowych rozwiązań w odniesieniu do wymiany informacji między reprezentantami pola polityki, pola przedstawicieli środków społecznego przekazu, pola akademickiego oraz pola społeczeństwa obywatelskiego. W przeciwnym wypadku coraz częściej będziemy świadkami bezwzględnej dominacji bezrefleksyjnej praktyki nad jakimikolwiek próbami namysłu w wymiarze indywidualnym oraz zbiorowym.

\section{Bibliografia}

Agné H. (2004), Democracy Reconsidered. The Prospects of its Theory and Practice during Internationalisation - Britain, France, Sweden and the EU, Stockholm University, Stockholm.

Almond G. (1990), A Discipline Divided. Schools and Sects in Political Science, Sage, Newbury Park.

Ashcroft L. (2016), How the United Kingdom voted on Thursday... and why, 24.06.2016, http://lordashcroftpolls.com/2016/06/how-the-united-kingdom-voted-and-why/, 29.09.2016.

Bellamy R., Attucci C. (2009), Normative Theory and the EU: Between contract and the Community, w: European Integration Theory, red. A. Wiener, T. Diez, Oxford University Press, Oxford.

Bellamy R., Castiglione D. (1997), Building the Union: The Nature of Sovereignty in the Political Architecture of Europe, „Law and Philosophy”, vol. 16, no. 4.

Bellamy R., Castiglione D. (2003), Legitimizing the Euro-polity and its regime. The normative turn in EU studies, „European Journal of Political Theory”, vol. 2, no. 1.

Berlin I. (1962), Does Political Theory Still Exist?, w: Philosophy, Politics and Society, red. P. Laslett, W. G. Runciman, Blackwell, Oxford.

Berlin I. (2000), Dwie koncepcje wolności, w: Cztery eseje o wolności, przeł. D. Grinberg, D. Lachowska, J. Łoziński, Wydawnictwo Zysk i S-ka, Poznań.

Bourdieu P. (2008), Zmyst praktyczny, przeł. M. Falski, Wydawnictwo Uniwersytetu Jagiellońskiego, Kraków.

Chryssochoou D. N. (2007), Demokracja Unii Europejskiej i jej deficyt, w: Unia Europejska. Organizacja i funkcjonowanie, red. M. Cini, przeł. G. Dąbkowski, PWE, Warszawa.

Cnudde C. F., Neubauer D. E. (red.) (1969), Empirical Democratic Theory, Markham, Chicago.

Czachór Z. (2004), Zmiany i rozwój w systemie Unii Europejskiej po Traktacie z Maastricht, atla2, Wrocław.

Czaputowicz J. (2007), Teorie stosunków międzynarodowych. Krytyka i systematyzacja, Wydawnictwo Naukowe PWN, Warszawa.

Dahl R. A. (1961), Who Governs? Democracy and Power in an American City, Yale University Press, New Haven.

Dworkin R. (1977), Taking Rights Seriously, Duckworth, London.

Easton D. (1953), The Political System: An Inquiry into the State of Political Science, Knopf, New York.

Easton D. (1969), The New Revolution in Political Science, „American Political Science Review”, no. 63.

manifestu behawioralistycznego w naukach politycznych, to szesnaście lat później - po objęciu stanowiska przewodniczącego APSA (ang. American Political Science Association) - ogłosił on rewolucję w stosunku do tak rozumianej optyki i od tej pory nawoływał do zastosowywania metody, którą określał jako post-pozytywistyczna w ramach sugerowanej przez niego rewolucji post-behawioralistycznej (ang. revolution of post-behaviouralism) (szerzej patrz: Easton, 1953; Easton, 1969; Dahl, 1961; Almond, 1990; Farr, 2008). 
Farr J. (2008), The new science of politics, w: The Cambridge History of Twentieth-Century Political Thought, red. T. Ball, R. Bellamy, Cambridge University Press, Cambridge.

Friese H., Wagner P. (2002), The nascent political philosophy of the European Union, „Journal of Political Philosophy", vol. 10, no. 3.

Gadamer H.-G. (2007), Prawda i metoda. Zarys hermeneutyki filozoficznej, przeł. B. Baran, Wydawnictwo Naukowe PWN, Warszawa.

Gottfried G. (2007), Teoria poznania. Od Kartezjusza do Wittgensteina, przeł. T. Kubalica, Wydawnictwo WAM, Kraków.

Habermas J. (1982), Zur Logik der Sozialwissenschaften, Suhrkamp, Frankfurt am Main.

Habermas J. (1985), Interesy konstytuujace poznanie, przeł. L. Witkowski, „Colloquia Communia”, nr 19.

Habermas J. (1988), On the Logic of the Social Sciences, przeł. S. W. Nicholson, J. A. Stark, MIT Press, Cambridge.

Habermas J. (1999), Teoria działania komunikacyjnego, przeł. A. M. Kaniowski, Wydawnictwo Naukowe PWN, Warszawa, t. I.

Habermas J. (2002), Teoria działania komunikacyjnego, przeł. A. M. Kaniowski, Wydawnictwo Naukowe PWN, Warszawa, t. II.

Hix S. (2005), The Political System of the European Union, Palgrave Macmillan, Basingstoke-New York.

Hix S. (2010), System polityczny Unii Europejskiej, przeł. A. Komasa, Wydawnictwo Naukowe PWN, Warszawa.

http://www.bbc.com, 29.09.2016.

http://www.electoralcommission.org.uk, 29.09.2016.

https://www.gov.uk/government/topical-events/scottish-independence-referendum/about, 29.09.2016.

Kaesler D. (2010), Weber. Życie i dzieło, przeł. S. Lisiecka, Oficyna Naukowa, Warszawa.

Koselleck R. (1994), Trzy światy obywatelskie? Wprowadzenie do porównawczej semantyki społeczeństwa obywatelskiego w Niemczech, Anglii i Francji - zarys dziejów teorii, w: Europa i społeczeństwo obywatelskie. Rozmowy w Castel Gandolfo, red. K. Michalski, przeł. B. Janicka, D. Lachowska, M. Łukasiewicz, A. Pawelec, W. Pięciak, W. Witalisz, Znak, Kraków.

Krasnodębski Z. (1983), Historia i krytyka. O teorii krytycznej Jürgena Habermasa, w: J. Habermas, Teoria i praktyka, przeł. M. Łukasiewicz, Z. Krasnodębski, PIW, Warszawa.

Krauz-Mozer B. (2007), Teorie polityki. Założenia metodologiczne, Wydawnictwo Naukowe PWN, Warszawa.

Lepenies W. (1997), Trzy kultury, przeł. K. Krzemieniowa, Wydawnictwo Poznańskie, Poznań.

Locke J. (1992), Dwa traktaty o rzqdzie, przeł. Z. Rau, PWN, Warszawa.

Marsh D., Furlong P. (2006), Skóra nie sweter: ontologia i epistemologia w politologii, w: Teorie i metody w naukach politycznych, red. D. Marsh, G. Stoker, przeł. J. Tegnerowicz, Wydawnictwo Uniwersytetu Jagiellońskiego, Kraków.

Miller D., Dagger R. (2008), Utilitarianism and beyond: contemporary analytical political theory, w: The Cambridge History of Twentieth-Century Political Thought, red. T. Ball, R. Bellamy, Cambridge University Press, Cambridge.

Nozick R. (1988), Anarchy, State and Utopia, Blackwell, Oxford.

Palumbo A., Scott A. (2008), Weber, Durkheim and the sociology of the modern state, w: The Cambridge History of Twentieth-Century Political Thought, red. T. Ball, R. Bellamy, Cambridge University Press, Cambridge.

Pascal B. (b.d.), Myśli, przeł. T. Żeleński (Boy), Instytut Wydawniczy Pax, Warszawa. 
Pettit P. (1998), Filozofia analityczna, w: Przewodnik po wspótczesnej filozofii politycznej, red. R. E. Goodin, P. Pettit, przeł. C. Cieśliński, M. Poręba, Książka i Wiedza, Warszawa.

Rawls J. (1995), Teoria sprawiedliwości, przeł. M. Panufnik, J. Pasek, A. Romaniuk, Wydawnictwo Naukowe PWN, Warszawa.

Sartori G. (1998), Teoria demokracji, przeł. P. Amsterdamski, D. Grinberg, Wydawnictwo Naukowe PWN, Warszawa.

Szacki J. (2002), Historia myśli socjologicznej, Wydawnictwo Naukowe PWN, Warszawa.

Szymczyński T. R. (2007), Dylematy wokót instytucji referendum europejskiego, „Rocznik Integracji Europejskiej”, INPiD UAM, Poznań.

Szymczyński T. R. (2008), Ireland, the Lisbon Treaty and the European Referendum, „European Governance", URGE, vol. 2, no. 2, http://www.urge.it/eg.html\#publications, 16.02.2013.

Szymczyński T. R. (2009a), Negocjowanie granic: od „Szóstki” do „Dziewiatki”. Rozszerzenie pólnocne Wspólnot Europejskich (1973): Wielka Brytania, Dania, Irlandia w WE, WNPiD UAM, Poznań, t. I.

Szymczyński T. R. (2009b), Negocjowanie granic: od „Dziewiatki” do „Dwunastki”. Rozszerzenie poludniowe Wspólnot Europejskich (1981-1986): Grecja, Hiszpania, Portugalia w WE, WNPiD UAM, Poznań, t. II.

Szymczyński T. R. (2009c), Negocjowanie granic: od „Dwunastki” do „Piętnastki”. Rozszerzenie pótnocne Unii Europejskiej (1995): Austria, Szwecja, Finlandia w UE, WNPiD UAM, Poznań, t. III.

Szymczyński T. R. (red.) (2009d), Negocjowanie granic: od „UE-15” do „UE-27”. Rozszerzenie wschodnie Unii Europejskiej. Część pierwsza - 'grupa luksemburska' (2004): Estonia, Polska, Republika Czeska, Stowenia, Wegry, Cypr w UE, WNPiD UAM, Poznań, t. IV.

Szymczyński T. R. (red.) (2009e), Negocjowanie granic: od „UE-15” do „UE-27”, Rozszerzenie wschodnie Unii Europejskiej. Część druga - 'grupa helsińska' (2004-2007): Litwa, Lotwa, Stowacja, Malta, Bułgaria, Rumunia w UE, WNPiD UAM, Poznań, t. V.

Szymczyński T. R. (2010), On Some Consequences of the Contemporary Shape of the European Referendum, w: The Road Europe Travelled Along. The Evolution of the EEC/EU Institutions and Policies, red. D. Preda, D. Pasquinucci, „Euroclio”, vol. 54, P. Lang, Bruxelles.

Szymczyński T. R. (2011a), Prezydencja w Unii Europejskiej. Teoretyczne i praktyczne aspekty z perspektywy podejścia Pierre'a Bourdieu, w: Priorytety prezydencji Polski w Radzie Unii Europejskiej. Analiza politologiczna, red. Z. Czachór, T. R. Szymczyński, Wydawnictwo Naukowe PWN, Warszawa.

Szymczyński T. R. (2011b), The Challenge of the Conceptualizations in Journalism. On Myths and Facts Regarding the Media Coverage of the Europeanization and Globalization Processes, w: News in Europe. Europe on News, red. A. Stępińska, Logos, Berlin.

Szymczyński T. R. (2013), Horyzonty sporu wokót istoty zjawiska deficytu demokratycznego w Unii Europejskiej, Dom Wydawniczy ELIPSA, Warszawa.

Tocqueville A. de (1976), O demokracji w Ameryce, przeł. M. Król, t. I-II, PIW, Warszawa.

Weber M. (2002), Gospodarka i społeczeństwo. Zarys socjologii rozumiejacej, przeł. D. Lachowska, Wydawnictwo Naukowe PWN, Warszawa.

Weber M. (2011), ,Wolność od wartościowania”- jej sens w naukach socjologicznych i ekonomicznych, w: M. Weber, Racjonalność, władza, odczarowanie, przeł. M. Holona, A. Kopacki, Wydawnictwo Poznańskie, Poznań.

Wimmel A. (2008), Die demokratische Legitimitaet europaeischen Regierens: ein Labyrinth ohne Ausgang?, „Integration”, no. 1.

Wimmel A. (2009), Theorizing the Democratic Legitimacy of European Governance: a Labyrinth with No Exit?, „European Integration”, vol. 31, no. 2. 
Woroniecka G. (2005), Hermeneutyka, w: Encyklopedia Socjologii, Oficyna Naukowa, Warszawa, Suplement.

Zeidler-Janiszewska A. (1996), Z ducha Diderota. Krótkie wprowadzenie do lektury esejów Wolfa Lepeniesa, w: W. Lepenies, Niebezpieczne powinowactwa z wyboru. Eseje na temat historii nauki, przeł. A. Zeidler-Janiszewska, Oficyna Naukowa, Warszawa.

\section{Streszczenie}

Brexit to zarówno nieoficjalne określenie referendum, które odbyło się w Zjednoczonym Królestwie Wielkiej Brytanii i Irlandii Północnej w dniu 23 czerwca 2016 roku, jak i nieformalna nazwa całego procesu opuszczania Unii Europejskiej przez Wielką Brytanię. Wydarzenie to wskazuje na wyzwania związane z problemami identyfikacyjno-definicyjnymi zarówno w odniesieniu do europejskiego procesu integracyjnego, jak i do dynamicznie transformujących się standardów działania i przekazywania informacji w ramach suwerennych państw narodowych w kontekście uobecniających się czynników wynikających zarówno z procesu europeizacji, jak i globalizacji. Ukazuje się tu między innymi wyzwanie związane z zagadnieniem odpowiedzialności poszczególnych grup zawodowych w odniesieniu do formy oraz treści przekazywanych informacji w przestrzeni publicznej. Tego rodzaju optyka prowadzi z kolei do pytań o rolę reprezentantów nauk społecznych i humanistycznych w przestrzeni polityki, a zatem o interakcje między polem polityki i polem nauki o niej.

Słowa kluczowe: Brexit, Unia Europejska, proces integracji europejskiej, referendum, perspektywa hermeneutyczna, perspektywa analityczna, perspektywa normatywna

\section{Brexit and the challenges of identification in relation to the European integration process from the hermeneutic perspective}

\section{Summary}

Brexit is an unofficial term for the referendum, that took place in United Kingdom of Great Britain and Northern Ireland at $23^{\text {rd }}$ June 2016, as well as an informal designation of the whole process of leaving the European Union by UK. This event indicates challenges of identificational and definitional problems with reference to the European integration process, as well as to dynamically transforming standards of activities and information transmissions within the frames of sovereign nation states in the context of manifestations of factors arising from Europeanisation and globalisation processes. Among other consequences here appears the challenge associated with the issue of responsibility of selected professional groups with reference to both form and content of information conveyed within public sphere. Such perspective leads in turn to the questions about the role of representatives of social sciences and humanities within the field of politics, that is interactions between the field of politics and the field of science devoted to it.

Key words: Brexit, European Union, European integration process, referendum, hermeneutic perspective, analytical perspective, normative perspective 